\title{
PEMANFAATAN MATLAB SIMULINK SEBAGAI MEDIA PEMBELAJARAN PRAKTIKUM SECARA DARING
}

\author{
Muhammad Isnaini', Mega Silfia Dewy ${ }^{2}$ \\ 1,2 Jurusan Pendidikan Teknik Elektro, Fakultas Teknik Universitas Negeri Medan \\ Imisnaini@unimed.ac.id, ${ }^{2}$ megasilfiadewy@unimed.ac.id
}

\begin{abstract}
Abstrak: Penelitian ini bertujuan untuk mendeskripsikan pemanfaatan software Matlab Simulink sebagai alternatif media pembelajaran praktikum secara daring pada matakuliah Praktek Mesin Listrik di Program Studi Pendidikan Teknik Elektro Fakultas Teknik Universitas Negeri Medan. Subjek penelitian terdiri dari seluruh mahasiswa angkatan 2019 yang mengambil matakuliah Praktek Mesin Listrik di kelas C dan D yang berjumlah 25 orang. Pengumpulan data ditempuh mulai dari observasi, wawancara, dan analisis dokumen yang berkaitan dengan permasalahan tersebut. Teknik validasi pada penelitian ini menggunakan validasi triangulasi teknik. Hasil penelitian menunjukkan bahwa pemanfaatan software Matlab Simulink dalam proses pembelajaran pada matakuliah Praktek Mesin Listrik cukup efektif membantu dosen dan mahasiswa dalam mencapai tujuan pembelajaran. Lebih lanjut, sebagian besar para mahasiswa memberikan respon positif terhadap proses pembelajaran yang dilaksanakan.
\end{abstract}

Kata Kunci : Matlab Simulink, media pembelajaran praktikum daring

\begin{abstract}
This research aims to describe the use of Matlab Simulink software as an alternative to online practicum learning media in the subjects of Electrical Machine Practice in the Electrical Engineering Education Study Program of the Faculty of Engineering, Medan State University. The study subjects consisted of all students of the class of 2019 who took electrical machine practice courses in grades $C$ and $D$ which amounted to 25 people. Data collection is taken starting from observation, interview, and analysis of documents related to the problem. The validation technique in this study uses the validation of triangulation techniques. The results showed that the use of Matlab Simulink software in the learning process in the electrical machine practice course is quite effective in helping lecturers and students in achieving learning goals. Furthermore, most of the students gave a positive response to the learning process carried out.
\end{abstract}

Keywords: Matlab Simulink, online practicum learning media

\section{PENDAHULUAN}

Indonesia khususnya dan dunia pada umumnya sedang menghadapi pandemi virus corona atau yang dikenal dengan Covid-19, sehingga banyak kegiatan yang harus dibatalkan atau diubah menjadi bentuk daring (dalam jaringan). Hal ini tentu menjadi tantangan yang besar untuk mata kuliah praktikum. Poin utama proses pembelajaran praktikum adalah aktivitas di laboratorium, dimana mahasiswa dilatih untuk pengembangan keterampilan (skill) sebagai aplikasi dari pengetahuan (knowledge) yang telah diperoleh di kelas. Salah satu cara dalam mengatasi hal tersebut adalah dengan pemanfaatan media pembelajaran untuk mendukung proses pembelajaran praktikum pada matakuliah Praktek Mesin Listrik. Peran media pada pembelajaran daring cukup dibutuhkan, begitu juga dalam proses pembelajaran praktek. Tidak menutup kemungkinan pemanfaatan media pembelajaran dilakukan mengingat perkembangan teknologi yang terus meningkat (Jiwandono, 2021).

Media erat kaitannya dengan proses pembelajaran. Dalam proses pembelajaran, media seringkali diartikan sebagai alat-alat grafis, photografis, atau alat elektronik yang berfungsi untuk menangkap, memproses, dan menyusun kembali informasi visual atau verbal (Wati, 2016: 2). Garlach dan Erly menyatakan bahwa media apabila dipahami secara garis besar adalah manusia, materi, atau kejadian yang membangun kondisi yang membuat siswa mampu memperoleh pengetahuan, keterampilan, atau sikap (Arsyad, 2019).

Menurut Kemp \& Dayton (1985), media pembelajaran memiliki konstribusi yang cukup penting dalam proses pembelajaran diantaranya (1) penyampaian pesan pembelajaran dapat lebih terstandar, (2) pembelajaran dapat lebih menarik, (3) pembelajaran menjadi lebih interaktif dengan menerapkan teori belajar, (4) waktu pelaksanaan pembelajaran dapat 
diperpendek, (5) kualitas pembelajaran dapat ditingkatkan, (6) proses pembelajaran dapat berlangsung kapanpun dan dimanapun, (7) sikap positif peserta didik terhadap materi pembelajaran serta proses pembelajaran dapat lebih ditingkatkan, dan (8) peran pendidik berubah kearah yang positif (Riyana : 2012).

Matakuliah Praktek Mesin Listrik merupakan matakuliah wajib yang ada di Prodi Pendidikan Teknik Elektro Fakuktas Teknik Universitas Negeri Medan. Pada matakuliah Praktek Mesin Listrik, dibutuhkan pemahaman terkait dengan konsep karakeristik dari mesinmesin listrik itu sendiri yang dapat dibuktikan dengan adanya praktikum di laboratorium. Ketiadaan proses praktikum dalam pembelajaran di laboratorium akibat pandemi Covid-19 membutuhkan alternatif solusi agar tetap terjadi proses transfer keterampilan tetap bisa berlangsung. Bentuk alternatif ini berupa pemanfaatan software Matrix Laboratory (Matlab) Simulink sebagai sebagai media pembelajaran praktikum secara daring. Metode ini dipilih agar mahasiswa tetap merasakan suasana praktikum luring sehingga proses pembelajaran keterampilan berpikir tingkat tinggi yang bermanfaat bagi pembentukan karakter, penguatan literasi, peningkatan kompetensi, dan pengayaan kurikulum tetap berjalan. (Saraswati \& Mertayasa, 2020).

Matrix Laboratory (Matlab) merupakan sebuah program yang berfungsi untuk menganalisis dan melakukan komputasi numerik dan merupakan suatu bahasa pemrograman matematika lanjutan yang terbentuk berdasarkan dasar pemikiran dengan menggunakan sifat dan bentuk matriks. Matlab saat ini berkembang menjadi environment pemrograman yang berisi fungsi-fungsi built in untuk melaksanakan tugas pengolahan sinyal, aljabar linier dan kalkulasi secara matematis. Interface ini juga menyediakan toolbox yang berisi fungsi tambahan untuk aplikasi khusus. Matlab bersifat extensible, artinya bahwa seorang pengguna dapat memasukkan fungsi baru untuk ditambahkan pada library ketika fungsi built-in yang tersedia tidak dapat melaksanakan tugastugas tertentu. (Math Works, Inc., 1993)

Matlab digunakan untuk menyelesaikan masalah-masalah yang melibatkan operasi matematika elemen, optimasi, aprokmasi, matriks, dan lain-lain. Dalam hal ini Matlab banyak digunakan untuk:

1. Pengembangan dan Algortima

2. Matematika dan komputasi
3. Analisis Numerik dan Statistik

4. Pengembangan Aplikasi Teknik

5. Analisis Data, Eksplorasi dan Visualisasi

6. Pemrograman pemodelan, Simulasi, dan Pembuatan Prototipe

Menurut Hanselman \& Littlefield (2000), salah satu fitur yang pada Matlab adalah Simulink yang merupakan program yang berorientasi objek (Object Oriented Program). Di dalam Simulink paket aplikasi yang banyak erat hubungannya dengan aplikasi komputer bidang engineering (Teknik Tenaga Listrik) yaitu power system blockset. Pada power system blockset ini banyak sekali library yang dapat dimanfaatkan untuk membantu proses pembelajaran dalam bidang teknik tenaga elektrik. Adapun beberapa power system blockset pada Simulink adalah (Math Works, Inc., 1993) :

1. Sources memiliki beberapa pustaka yaitu : digital clock, clock, constant, sine wave, step input, pulse generator random number, form file, signal generator, signal, band limited white noise, repeating squance.

2. Discrete memiliki beberapa pustaka yaitu : unit delay, filter, discreate state-space, first older hold, discrete time integrator, transfer function, discrete time limited integrator, discrete zero-pole.

3. Sinks memiliki beberapa pustaka yaitu : scope, graph, XY graph, stop simulation, hit crossing, to workspace, to file, auto-scale graph.

4. Connections memiliki beberapa pustaka yaitu : outport, inport, demux, mux.

5. Extras memiliki beberapa pustaka yaitu : simulink demos, most commonly used blocks, conversion, PID controllers, flip-flop, analyzers, controllers, filters, robust control demo, systems ID, mu tools demos, neural networks.

6. Linear memiliki beberapa pustaka yaitu : sum, gain, integrator, matrix gain, slider gain, transfer function, zero pole, state space, derivative, inner product.

7. Nonlinear memiliki beberapa pustaka yaitu : relay, sign, switch, saturation, quantizer, memory, transport delay, variable transport delay, matlab function, function, reset integrator, backlash, combinatorial logic, logical operator, relational operator, product, abs, look up table, 2-D look up table, dead zone, dan rate limite. 
Secara garis besar model simulasi yang include di kelompokan menjadi enam yaitu :

1. Simple Model, meliputi : linear filter, transient analysis, linear transformer, saturable transformer, AC surge Arrester, dan lain-lain,

2. Power Electronics Model, meliputi : singlephase rectifier, three-phase Rectifier, thyristor converter, mosfet converter, dan lain-lain,

3. Machine Models, meliputi : simplified alternator, synchronous machine, asynchronous machine, steam turbin and governor system, machine and load flow, dan lain-lain,

4. Drive Models, meliputi : starting a DC motors, chopper-fed DC motor drive (continuous and discrete) dan AC motor drive-vector control.

5. Power Utility AC/DC Network Models, meliputi : single/three phase series compesated network, simple-6 pulse /complete-12 pulse HVDC transmission system, single pole reclosing of a three phase line.

6. Measurement and Control Models, meliputi : three phase programmable source and sequence analysis, three phase programmable source PLL, FFT Analysis Design Simulation.

Penelitian ini dilakukan dengan tujuan untuk mendeskripsikan proses pembelajaran pada matakuliah Praktek Mesin Listrik secara daring dengan menggunakan software Matlab Simulink. Diharapkan dengan software tersebut dalam pembelajaran matakuliah Praktek Mesin Listrik dapat meningkatkan pemahaman karakteristik mesin listrik oleh mahasiswa.

\section{METODE PENELITIAN}

Penelitian ini menggunakan metode penelitan kualitatif. Penelitian dilakukan dengan cara mengetahui permasalahan pada proses pembelajaran secara daring. Pengumpulan data dilalui dengan observasi, wawancara hingga analisis dokumen yang berkaitan dengan permasalahan tersebut. Prosedur penelitian yang digunakan mengacu pada teori prosedur penelitian kualitatif Danim dan Darwis (2003: 80).

Subjek penelitian terdiri dari seluruh mahasiswa angkatan 2019 yang mengambil matakuliah Praktek Mesin Listrik di kelas C dan $\mathrm{D}$ yang berjumlah 25 orang. Adapun prosedur penelitiannya adalah merumuskan masalah sebagai fokus penelitian, mengumpulkan data di lapangan, menganalisis data, merumuskan hasil studi, dan menyusun rekomendasi.

Desain penelitian yang dilakukan dalam studi ini adalah pendekatan kualitatif, yang menekankan analisisnya pada data yang telah diperoleh pada saat penelitian dilaksanakan.

Teknik validasi pada penelitian ini menggunakan validasi triangulasi teknik. Triangulasi teknik untuk menguji kredibilitas data yang dilakukan dengan cara mengecek data kepada sumber yang sama dengan teknik yang berbeda (Sugiyono, 2014: 127). Misalnya data diperoleh dengan wawancara lalu dicek dengan observasi, dokumentasi atau kuisioner. Kemudian proses analisis data dilakukan melalui dua fase selama (on going) dan setelah selesainya (after) pengumpulan data

\section{HASIL DAN PEMBAHASAN}

Matakuliah Praktek Mesin Listrik merupakan matakuliah lanjutan dari matakuliah Mesin-Mesin Listrik yang terdiri dari tiga sub materi, yaitu transformator, motor dan generator. Matakuliah Praktek Mesin Listrik bertujuan untuk mengetahui karakteristik yang dimiliki oeh ketiga sub materi tersebut. Dalam penelitian ini, software Matlab Simulink digunakan untuk mencari tahu karakeristik motor DC Shunt. Sebelumnya, mahasiswa harus mengetahui teknik pemodelan yang ada pada Simulink.

Proses pembelajaran matakuliah Praktek Mesin Listrik dilaksanakan secara daring melalui pemanfaatan Zoom Meeting, e-Learning SIPDA dan WhatsApp. Zoom Meeting digunakan untuk proses pertemuan tatap muka secara virtual. e-Learning SIPDA digunakan untuk pemberian tugas dan presensi siswa. Kemudian WhatsApp digunakan untuk menginformasikan segala hal tentang proses pembelajaran dan untuk mengontrol siswa dalam belajar. Metode pembelajaran yang digunakan pada proses adalah tanya jawab, ceramah, dan demonstrasi secara daring. Metode ceramah dilakukan pada saat proses belajar mengajar berlangsung secara tatap maya melalui video conference. Metode ceramah ini bertujuan untuk memberi penjelasan kepada siswa tentang pengulangan materi. Metode tanya jawab dilakukan pada saat proses pembelajaran berlangsung secara daring melalui video conference. Kemudian demonstrasi digunakan untuk memberi pemahaman materi praktek melalui video-video tutorial. Metode ini 
bertujuan untuk membantu kemudahan siswa dalam proses pembelajaran praktek.

Pada pembelajaran praktikum secara daring matakuliah Praktek Mesin Listrik di Prodi Pendidikan Teknik Elektro, digunakan juga media pembelajaran berupa software Matlab Simulink. Matlab Simulink digunakan untuk membuat pemodelan dari karakteristik motor DC Shunt sebagai bahan praktek mahasiswa.

Pada motor shunt seperti ditunjukkan pada Gambar 1, kumparan medan shunt dibuat dengan banyak lilitan kawat kecil sehingga mempunyai tahanan yang tinggi. Motor hunt mempunyai rangkaian jangkar dan medan yang dihubungkan paralel sehingga memberikan kekuatan medan dan kecepatan motor yang sangat konstan. Kecepatan motor dapat dikontrol di atas kecepatan dasar, dan akan menjadi berbanding terbalik dengan arus medan. Ini berarti motor shunt berputar cepat dengan arus medan rendah dan berputar lambat pada saat arus medan ditambah. Motor shunt dapat melaju pada kecepatan tinggi jika arus kumparan medan hilang.
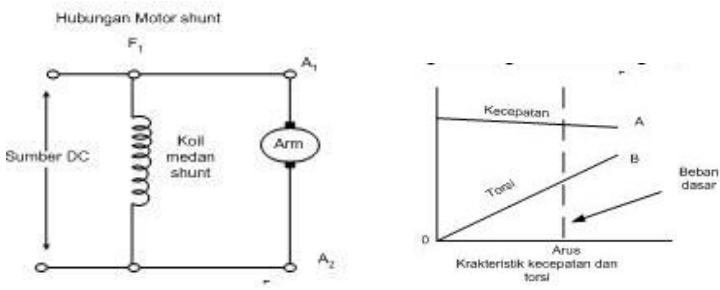

Gambar 1. Motor DC Shunt

Pada percobaan motor DC Shunt dengan Matlab Simulink, mahasiswa mencoba mencari tahu karakteristik motor DC Shunt yaitu pengaruh perubahan pembebanan /Torsi ke rotor (T) terhadap Arus jangkar (Ia) dan putaran rotor (Nr). Pada Gambar 2 dan Gambar 3 merupakan pemodelan dari motor DC Shunt.

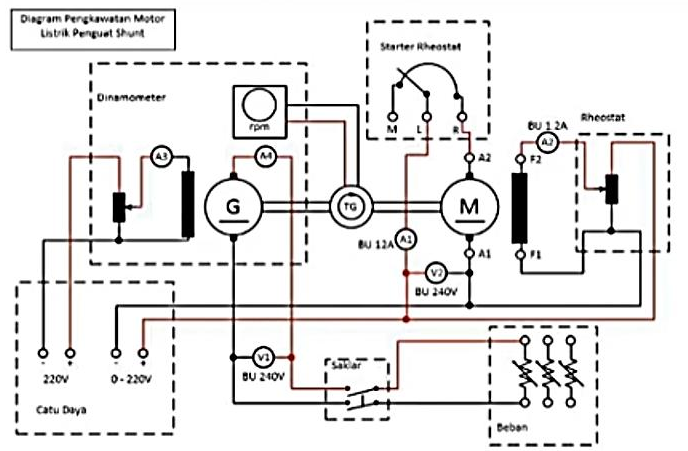

Gambar 2. Diagram pengawatan Motor DC Shunt

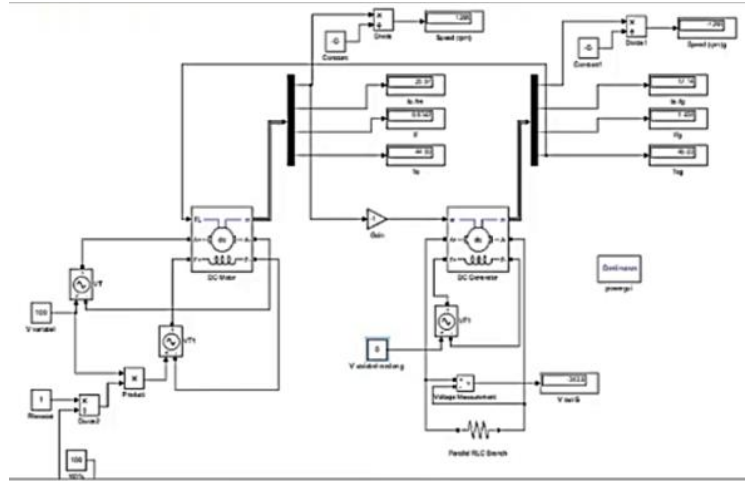

Gambar 3. Pemodelan Motor DC Shunt dengan Menggunakan Matlab Simulink

Pada motor shunt, rangkaian kumparan medan terhubung pararel dengan kumparan rotor. motor DC shunt mempunyai karakteristik regulasi tegangan yang baik. Kumparan medan dapat disuplai dari sumber tegangan sendiri maupun disambungkan dengan kumparan jangkar. Keuntungannya adalah memungkinkan dikendalikannya kumparan medan dan kumparan jangkar secara independen.

Pada Gambar 4 terlihat bahwa dengan penambahan beban, sehingga input akan menyebabkan perlambatan putaran motor namun tidak terlalu besar. Sehingga penambahan beban tidak berpengaruh terlalu besar terhadap putaran motor. Kelebihan dari Motor DC jenis ini yaitu tidak terlalu membutuhkan banyak ruangan karena diameter kawat kecil dan pada percobaan matlab simulink diketahui bahwa Motor DC Shunt memiliki arus start yang besar yaitu 92,99 A. Sedangkan kelemahannya yaitu daya keluaran yang dihasilkan oleh motor menjadi kecil karena arus penguatnya kecil.

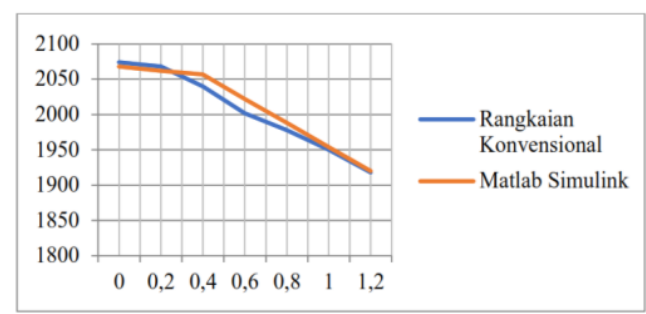

Gambar 4. Karakteristik putaran terhadap beban motor DC shunt pada percobaan rangkaian konvensional

Proses pembelajaran pada matakuliah Praktek Mesin Listrik yang dilakukan secara daring dengan menggunakan Matlab Simulink membuat mahasiswa lebih senang mengikuti perkuliahan daring. Media pembelajaran ini juga cukupmembantu mahasiswa dalam proses 
belajar mulai dari memahami hingga mempraktikkan sendiri sub materi motor DC Shunt. Hal ini dibuktikan dengan respon mahasiswa mengenai proses pembelajaran yang diberikan melalui e-learing SIPDA.

Pada pertanyaan pertama, yaitu tingkat kesulitan dalam mengikuti proses pembelajaran praktikum menggunakan Matlab Simulink yang mendapatkan respon keselurahan kelas $\mathrm{C}$ dan $\mathrm{D}$ mahasiswa yang berjumlah 25 orang. Dari itu, ada 18 mahasiswa memberikan jawaban bahwa tidak ada kesulitan dalam mengikut proses pembelajaran motor DC Shunt secara daring menggunakan Matlab Simulink. Kemudian sisanya memberikan jawaban berbeda, ada siswa yang merasa sedikit kesulitan dan ada siswa yang merasa sulit.

Pertanyaan kedua, yaitu tentang penggunaan Matlab Simulink sebagai media pembelajaran praktikum secara daring apakah lebih menarik bagi mahasiswa. Jawaban respon ini diantaranya ada 20 mahasiswa yang menyatakan bahwa proses pembelajaran praktikum daring menggunakan Matlab Simulink dianggap lebih menarik. Kemudian 3 mahasiswa memberikan respon kurang menarik.

Pertanyaan ketiga yaitu manfaat pembelajaran motor DC Shunt secara daring menggunakan Matlab Simulink, salah satunya adalah membuat siswa lebih semangat untuk belajar. Pertanyaan ini mendapatkan respon dari 20 siswa yang menyatakan lebih semangat untuk belajar, karena proses pembelajaran praktek dapat dilaksanakan dalam cara alternatif. Kemudian 5 siswa memberikan respon yang berbeda-beda. Masih ada siswa yang lebih semangat apabila dapat melakukan praktek secara langsung, dan masih ada yang tidak terlalu semangat karena perangkat yang mereka punya seperti laptop masih kurang mendukung.

Berdasarkan hasil yang diperoleh, dapat terlihat bahwa pembelajaran praktikum secara daring pada matakuliah Praktek Mesin Listrik menggunakan software Matlab Simulink pada sub materi motor DC Shunt menjadi lebih lancar dan tujuan pembelajaran dapat tercapai walaupun dilaksanakan secara daring. Pembelajaran daring matakuliah Praktek Mesin Listrik yang sebelumnya hanya mengulang materi pada matakuliah Mesin-Mesin Listrik, menjadi lebih efektif dan efisien dengan menggunakan software Matlab Simulink karena cukup memudahkan mahasiswa untuk belajar kapanpun dan dimanapun.

\section{PENUTUP}

Berdasarkan hasil penelitian dapat disimpulkan bahwa pembelajaran praktikum secara daring pada matakuliah Praktek Mesin Listrik di Prodi Pendidikan Teknik Elektro Fakultas Teknik Universitas Negeri Medan dapat terlaksana dengan menggunakan software Matlab Simulink. Pemodelan Motor DC Shunt pada Matlab Simulink mempermudah dosen dalam melaksanakan proses pembelajaran matakuliah Praktek Mesin Listrik.

Proses pembelajaran praktik motor DC Shunt secara daring tidak sepenuhnya terlaksana dengan baik, ada kekurangan dalam proses pembelajaran seperti beberapa siswa belum mempunyai laptop yang mendukung, ruang penyimpanan laptop mahasiswa yang tidak cukup, dan keterbatasan paket data internet.

Penggunaan software Matlab Simulink dapat dijadikan salah satu solusi bagi dosen untuk melaksanakan proses pembelajaran praktek pada matakuliah Praktek Mesin Listrik secara daring. Penelitian selanjutnya dapat diproyeksikan guna mengkaji serta mengembangkan media pembelajaran lain yang lebih menarik dan efektif, mengingat bahwa pembelajaran harus selalu diimbangi dengan kemajuan teknologi.

\section{DAFTAR PUSTAKA}

Arsyad, A. (2019). Media Pembelajaran : Revisi. Jakarta: Rajagrafindo Persada.

Hanselman, D. \& Littlefield. (2000) MATLAB : Bahasa Komputasi Teknis, Komputasi, Visual, Pemrograman. Pearson Education Asia : New Jersey.

Jiwandono, M. D., Octavianingrum, D., \& Djatmiko, G. (2021). Pemanfaatan Logic Pro X Dan E-Gamelan Sebagai Alternatif Media Pembelajaran Praktik Karawitan Secara Daring. Indonesian Journal of Performing Arts Education, 1(2). 27750884. https://doi.org/10.24821/ijopaed

Math Works, Inc. (1993). MATLAB User's Guide, High performance Numeric Computation and Visualization Software. The Math Works, Inc. : United States. . (1993). SIMULINK User's Guide. Natick : Massachusets.

Riyana, Cepy. (2012). Media Pembelajaran : Edisi Revisi. Dirjen Pendidikan Islam Kementrian Agama RI : Jakarta.

Saraswati, N. L. P. A., \& Mertayasa, I. N. E. (2020). Pembelajaran Praktikum Kimia 
pada Masa Pandemi COVID-19:

Qualitative Content Analysis

Kecenderungan Pemanfaatan Teknologi Daring. Wahana Matematika Dan Sains: Jurnal Matematika, Sains, Dan Pembelajarannya, 14(2), 2549-6727. http://dx.doi.org/10.23887/wms.v14i2.28 297

Sugiyono, S. (2014). Metode Penelitian Penelitian Kuantitatif, Kualitatif dan $R \& D$. Bandung: Alfabeta.

Wati, E. R. (2016). Ragam Media Pembelajaran (A. Jarot, Ed.). Jakarta: Kata Pena. 